\title{
Potential of natural bed soil in adsorption of heavy metals in industrial waste landfill
}

\author{
${ }^{1}$ *M. Esmaeili Bidhendi; ${ }^{1}$ A. R. Karbassi; ${ }^{1}$ A. Baghvand; ${ }^{2}$ M. Saeedi; ${ }^{1}$ A. H. Pejman \\ ${ }^{1}$ Graduate Faculty of Environment, University of Tehran, Tehran, Iran \\ ${ }^{2}$ Environmental Research Laboratory, School of Civil Engineering, Iran University of Science and Technology, \\ Tehran, Iran \\ Received 28 April 2009; revised 24 June 2009; accepted 30 January 2010; availaEOHonline 1 June 2010
}

\begin{abstract}
Development of higher welfare could not be realized unless by energy consumption and other natural resources. Growth of industrial complexes has shown an unprecedented trend during recent years. Many of these towns have no treatment systems for the industrial wastes leachates. Besides, the chemical composition of wastes in such complexes varies considerably due to the different kinds of industries. It is endeavored in the present work to study the natural potential of soil to treat leachate of such industrial wastes. For this purpose, the Aliabad industrial complex in Tehran - Garmsar road was selected as the study area. The potential of adsorption of elements such as nickel, copper, cadmium, zinc, chromium, lead and manganese was investigated. The results indicated that the soil potential to adsorb heavy metals (except for manganese) was very high (95 \%) in the adsorption of heavy metals (except for manganese). Further, chemical partitioning studies revealed that heavy metals are associated with various soil phases such as loosely bonded ions, sulfide and organics to various extents. Among the mentioned soil phases, one can deduce that major portion of metal contaminants is absorbed as loosely bonded ions. Organic bond and sulfide bond are in the $2^{\text {nd }}$ and $3^{\text {rd }}$ positions of metal contaminants adsorption, respectively. The results of the present study apparently showed that soil column had ample capacity to adsorb metal contaminants. Thus, determination of soil potential in adsorption of heavy metals during site selection is as important criteria.
\end{abstract}

Keywords: Heavy metal; Industry; Leachate; Waste landfill

\section{INTRODUCTION}

Industrial complexes are one of the major industrial centers, which play a remarkable role in progress and promotion of industry in developing countries. The concept beyond establishment of industrial complex is to control pollution emission through an integrated manner. Normally, this observation related to sanitary and environmental principles has lead to increased amount of pollution in these complexes. Industrial activities are identified as a major cause for metal contamination of the ecosystem (Charlesworth et al., 2003; Al-Khashman, 2004; Banat et al., 2005; Karbassi et al., 2008). Depending on type of industrial activities, huge amount of industrial disposal is produced. Due to lack of properly equipped plants and sanitary dumping sites operated within the required standards, the industrial wastes are released in an adhoc manner to the environment. Because of possessing highly

\footnotetext{
凶*Corresponding Author Email: m.esmaieli@gmail.com
}

Tel.: +98912 1836 670; Fax: +9821 66407719 hazardous ingredient like different kinds of heavy metals, they are considered as the main sources of pollution. In many of the developing countries, solid wastes are dumped in open areas regardless of any eco-sanitary concern (Vastanthi et al., 2008). Solid waste leachate which is the greatest that treat to groundwater possess various chemical and biological contaminants (Longe and Enekwechi, 2007; Mahvi, 2008; Suthar and Singh, 2008). Hence, regulatory measures related to the waste management and environmental conservancy is significant in industrial complexes. Indeed, due to the presence of different chemical compositions such as heavy metals, hydrocarbons and poisonous materials, as well as potential capability of producing leachate, industrial wastes and landfills without environmental safety are considered as one of the pollutant sources of ground water and surface water (Zheng et al., 1991; Lee and Jones, 1993; Christensen et al., 2001; Cheng et al., 
2004; Chen et al., 2005; Nouri et al., 2008; Malakootian et al., 2009). The produced leachates is normally comprised of organic and inorganic compositions. In addition, with elapse of a time, the produced leachate permeates into ground systems leading to change of physical and chemical properties of groundwater (Vastani et al., 2008). The leachate composition and its pollution intensity depend on many aspects such as landfill age, waste ingredients and hydraulic conditions of landfill (Qasim and Chiang, 1994; Okafor and Opuene, 2007). Produced leachate essentially contain elements such as cadmium, manganese, potassium, nitrogen, heavy metals (e.g. iron, copper, manganese, chromium, nickel, lead) and organic compositions like poly aromatic hydrocarbons, Acetone, Benzene, Toluene, Chloroforms (Freeze and Cherry, 1979; Lee et al., 1986; Bagchi, 1989).

The density of mentioned materials in leachates and ground water depends on wastes composition (Fang, 1995). Leachates travel from unsaturated zones to ground waters surfaces. Some of the pollutant materials may be adsorbed by soil particles within their movement through the several of soil strata (Fang, 1995). When the leachate is mixed up with groundwater, it would be dispersed in the flow direction that eventually leads to spatial pollution (Vastani et al., 2008). The rate and intensity of pollution in aquifers depend on rate of pollutants transfer from soil (Vastani et al., 2008). Thus many factors in soil such as cation exchange capacity (CEC), clay minerals, organics and carbonates must be studied. Nevertheless, due to simplicity, low cost and efficiency and ignorance, solid wastes are often dumped in buried locations (Barrett and Lawlor, 1995). Bury and dump of solid wastes in dump places leads to many environmental problems due to emission of odor, air pollutants and effluents (Fatta et al., 1999; Panjeshahi and Ataei, 2008). Also landfill is known to be sources of groundwater pollution (Allen, 2001). Gharaibeh and Masad (1989) have shown that dissolution of solid waste by rain produces a noticeable amount of polluted water in the form of leachate. Environmental problem of wastes are much more serious with industrial wastes that contain hazardous chemicals. This implies that contaminants may remain in their initial form for a long period (Fatta et al., 1999). Potentially becoming hazardous to the exposed ecosystems. Issues related to heavy metal associated with industrial waste require considerable attention. For example, toxicological impacts of various heavy metals, irrespective of their uses in the industry are known to be of an environmental concern (Aucott, 2006). For example, lead has been reported to cause various diseases such as brain damage, anorexia, mental deficiency and anemia also cadmium has been implicated in agonistic and antagonistic effects on hormones and enzymes leading to many of malformations such as renal damage (Lewis, 1991; Low et al., 2000; Bulut and Baysal, 2006). Likewise, $\mathrm{Pb}$ and $\mathrm{Cd}$ are classified as carcinogens (EPA 1992b; Pekey, 2006). Nevertheless, because of owning exclusive characteristics, some of them such as Hg, Cd and $\mathrm{Pb}$ are often used in production of industrial products like different batteries, switches, electronic boards and so on (Aucott, 2006). Futta et al. (1997) showed in their study conducted on Athena Region that groundwater quality is highly influenced by leachate. High density of leachate in ground water of Athena region was also found. Heavy metals, investigated in this study, were $\mathrm{Ni}, \mathrm{Mn}, \mathrm{Cr}, \mathrm{Pb}, \mathrm{Zn}, \mathrm{Cu}$ and $\mathrm{Cd}$, each of which has been reported for various health problems non-biodegradable and with the possibility of accumulation in the food chain (Langston, 1990; Nameni et al., 2008). This study attempts to investigate the impact of the heavy metal in the industrial waste disposal site of Aliabad industrial complex on the soils, by natural bed soil as an adsorption media to reduce such contamination.

\section{Study area}

Aliabad industrial complex is one of the first industrial complexes of Tehran Province located in Tehran - Garmsar road, 55 km away from Tehran City. The study location is situated at $35^{\circ} 21^{\prime} 23^{\prime \prime} \mathrm{N}$ and $51^{\circ} 55^{\prime} 59^{\prime \prime} \mathrm{E}$. The active industries in the complex involve metal, minerals, food, electricity, electronic, textile and chemicals. The geographical location of the investigated complex is shown in Fig. 1.

\section{MATERIALS AND METHODS}

A sample was extracted at $1 \mathrm{~m}$ depth (intact) from the site by a hand auger. The sample was transferred into a polyethylene pipe and transported to the laboratory of Faculty of Environment, University of Tehran. Industrial leachates were collected in High Density Poly-ethylene (HDPE) bottles. A part of leachates was filtered for trace metal measurement by atomic absorption spectrophotometry (AAS). Then the 


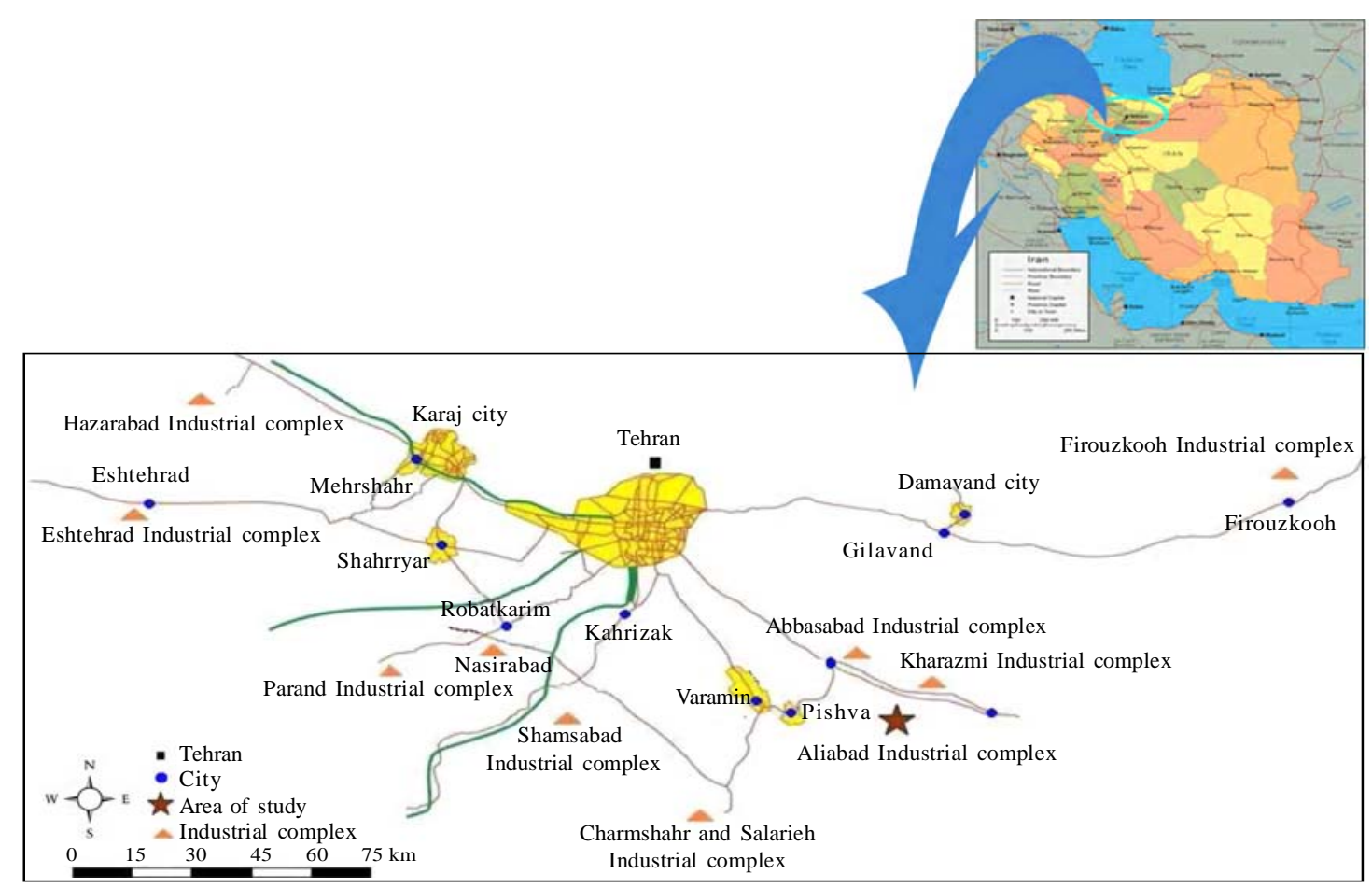

Fig. 1: Study area map

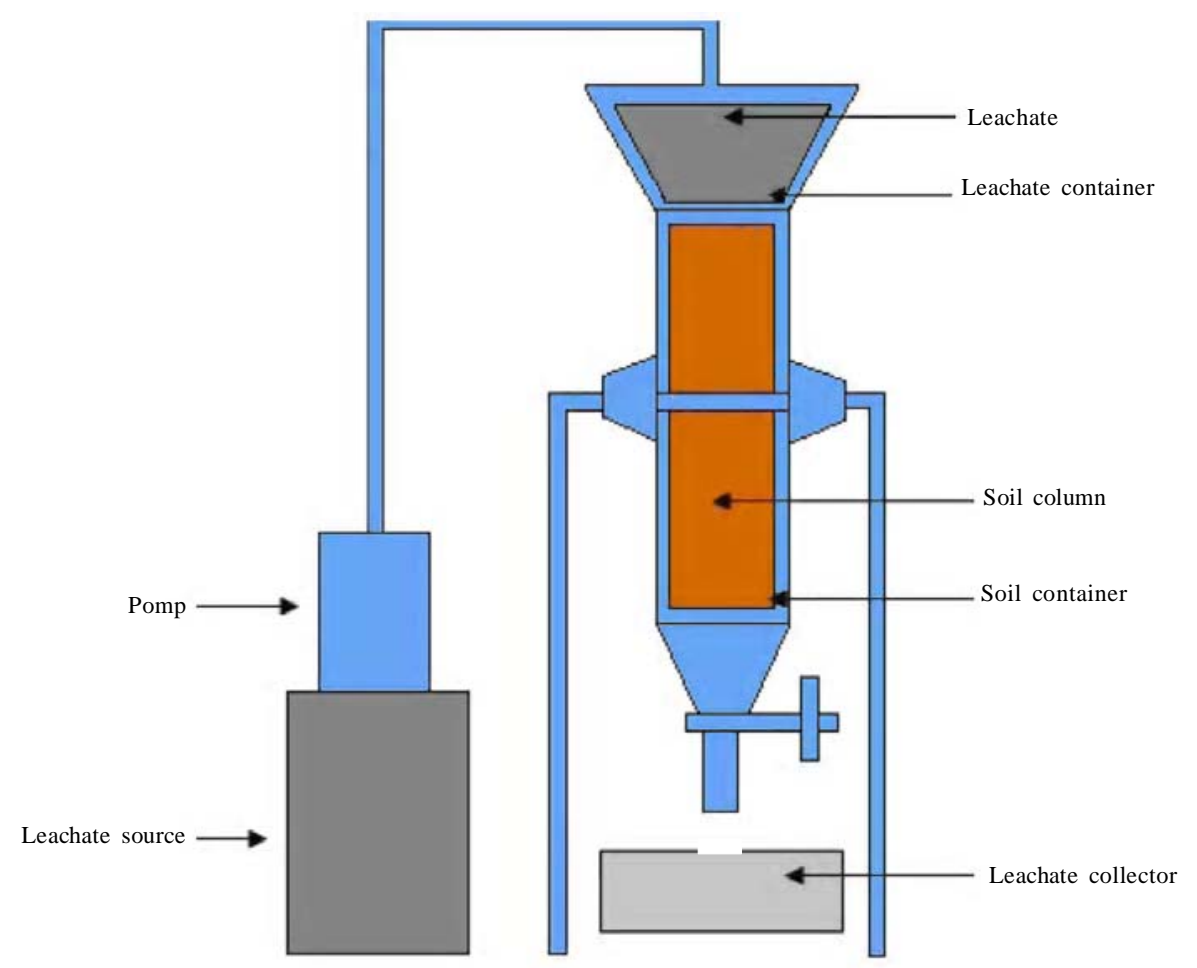

Fig. 2: Schematic view of the soil column 
remaining leachates were poured on the top of soil sample and the outlet leachate was collected at the bottom of the soil column. The experiment was carried out for 35 continuously days. The schematic view of the soil column is depicted in Fig. 2. Two sets of soil samples were selected for chemical analysis. The first set includes natural soils from area of study and the second set encompasses the soil column that was used for purification of heavy metals in laboratory. At the end of $35^{\text {th }}$ day, we repeated soil sampling at the same height as mentioned before. Then the obtained seven soil samples and eight collected leachate samples were prepared in accordance to Environmental Protection Agency (EPA) method number 3010 A (EPA, 1992a) and $7000 \mathrm{~B}$ (EPA, 2007). The concentrations of elements in samples have been analyzed using flame atomic absorption spectrophotometer.

\section{RESULTS AND DISCUSSION}

The results of soil analysis show that the project location has mainly coarse grains that are classified in GW-GM, GM, SM, SC-SM classes. It should be noted that fine texture of soil were classified in CLML and ML classes. The soil cohesion coefficient was determined to be $0.1 \mathrm{~kg} / \mathrm{cm}^{2}$ and the natural specific weight of the soil was about $1.85 \mathrm{~g} / \mathrm{cm}^{3}$. Complementary data of soil column are presented in Table 1.

Table 2 shows the concentration of $\mathrm{Ni}, \mathrm{Cu}, \mathrm{Cd}, \mathrm{Zn}$, $\mathrm{Pb}, \mathrm{Cr}$ and $\mathrm{Mn}$ in the leachates that are collected at 5 , $10,15,20,25,30$ and 35 days from bottom of the soil column.

For instance, in this study, it was observed that the initial concentration of $\mathrm{Mn}$ in the leachate was $0.75 \mathrm{mg} / \mathrm{L}$, which was decreased to $0.39 \mathrm{mg} / \mathrm{L}$ after release of leachate over the soil sample. Other elements also such as $\mathrm{Cr}, \mathrm{Pb}, \mathrm{Zn}, \mathrm{Cd}, \mathrm{Cu}$ and Ni were absorbed and dissipated by more than $95 \%$. The results of Table 2 show that major portions of contaminants were absorbed in the first 5 days of leachate release into the soil column. After accomplishment of first level of experiments, the contents of elements were measured in different sections of soil (Table 3). The comparison of elemental concentrations of intact soil with those of contaminated ones at various column depths was determined and provided the first line of proof that heavy metals adsorption by soil layers. Adsorption of heavy metals by soil layers at different depths should not be considered as purification of metal contaminants. In fact, type of association of elements with different phases of soil is very important in their fate. Typically, five important combinations naming "Loosely bonded ions", "Sulfide bond”, “Organic-Metal bond”, "Resistant bond" and "Within lattice bond" are critical in understanding the contaminant dynamics of adsorption. The first three bonds are known as anthropogenic sources and the last two bonds are indicative of lithogenous sources. However, it is worthy to note that the contaminants in any of three anthropogenic bonds can be released due to partial variations in physical and chemical properties of soil. Such release may lead to surface and ground water pollution. The Sulfide bond that is indicative of redox conditions can actually occur where oxygen is depleted in the environment. The presence of elements such as Fe and $\mathrm{Mn}$ in this combination indicates formation of sulfides in the environment. It might be argued that Organo-Metallic bonds are more resistant to environmental changes than the other two discussed bonds. The results of mentioned combinations are presented in Table 4-6.

Table 1: Soil complementary data at Aliabad industrial complex

\begin{tabular}{|c|c|c|c|c|c|c|c|}
\hline $\begin{array}{l}\text { Depth } \\
(\mathrm{cm})\end{array}$ & $\begin{array}{c}\text { Layers } \\
\text { classification }\end{array}$ & $\mathrm{pH}$ & $\begin{array}{l}\text { Natural density } \\
\left(\mathrm{g} / \mathrm{cm}^{3}\right)\end{array}$ & $\begin{array}{c}\text { Dry density } \\
\left(\mathrm{g} / \mathrm{cm}^{3}\right)\end{array}$ & Moisture (\%) & $\begin{array}{c}\text { Dissolved } \\
\text { chloride (Cl) }\end{array}$ & $\begin{array}{c}\text { Solvable } \\
\text { sulphate }\left(\mathrm{SO}_{3}\right)\end{array}$ \\
\hline 0 & GW-GM & 8.64 & 1.83 & 1.78 & 5.1 & 0.05 & 0.39 \\
\hline 20 & GM & 8.52 & 1.60 & 1.56 & 5.6 & 0.06 & 0.35 \\
\hline 40 & SM & 8.2 & 1.61 & 1.59 & 5.7 & 0.04 & 0.38 \\
\hline 60 & SC-SM & 8.2 & 1.62 & 1.55 & 6.2 & 0.06 & 0.33 \\
\hline 80 & CL-ML & 8.05 & 1.65 & 1.61 & 6.3 & 0.08 & 0.27 \\
\hline 100 & ML & 7.98 & 1.7 & 1.66 & 6.6 & 0.09 & 0.25 \\
\hline $\begin{array}{l}\text { GW-GN } \\
\text { GM: Si } \\
\text { SM: Sil }\end{array}$ & $\begin{array}{l}\text { raded gravel wi } \\
\text { with sand }\end{array}$ & id sa & & $\begin{array}{l}\text { SC-SM: Silty cl } \\
\text { CL-ML: Silty C } \\
\text { ML: Sandy silt }\end{array}$ & $\begin{array}{l}\text { sand } \\
\text { with sand } \\
\text { gravel }\end{array}$ & & \\
\hline
\end{tabular}


Int. J. Environ. Sci. Tech., 7 (3), 545-552, Summer 2010

Table 2: Metal concentrations in the seven leachate samples collected from bottom of soil column and initial leachate

\begin{tabular}{lrcccccc}
\hline & \multicolumn{7}{c}{ Elements $(\mathrm{mg} / \mathrm{L})$} \\
\hline Sample & $\mathrm{Ni}$ & $\mathrm{Cu}$ & $\mathrm{Cd}$ & $\mathrm{Zn}$ & $\mathrm{Pb}$ & $\mathrm{Cr}$ & $\mathrm{Mn}$ \\
Initial leachate & 9.5 & 3.5 & 2.3 & 4.5 & 4.5 & 135 & 0.75 \\
Leachate at day 5 & 0.138 & 0.289 & 0.044 & 0.163 & 0.579 & 0.63 & 0.39 \\
Leachate at day 10 & 0.071 & 0.228 & 0.013 & 0.152 & 0.551 & 0.64 & 0.39 \\
Leachate at day 15 & 0.095 & 0.269 & 0.012 & 0.129 & 0.548 & 0.71 & 0.39 \\
Leachate at day 20 & 0.016 & 0.291 & 0.011 & 0.104 & 0.679 & 0.64 & 0.39 \\
Leachate at day 25 & 0.040 & 0.335 & 0.028 & 0.092 & 0.599 & 0.63 & 0.39 \\
Leachate at day 30 & 0.064 & 0.643 & 0.039 & 0.105 & 0.651 & 0.58 & 0.40 \\
Leachate at day 35 & 0.120 & 0.321 & 0.055 & 0.074 & 0.479 & 0.54 & 0.39 \\
Max. & 0.138 & 0.643 & 0.055 & 0.163 & 0.679 & 0.71 & 0.40 \\
Min. & 0.016 & 0.228 & 0.011 & 0.074 & 0.479 & 0.54 & 0.39 \\
SD $^{*}$ & 0.043 & 0.138 & 0.017 & 0.032 & 0.067 & 0.053 & 0.003 \\
\hline
\end{tabular}

* SD: Standard Diviation

Table 3: Concentration of Heavy metals in various soil depths

\begin{tabular}{|c|c|c|c|c|c|c|c|}
\hline \multicolumn{8}{|c|}{ (mg/kg) } \\
\hline Sample & $\mathrm{Ni}$ & $\mathrm{Cu}$ & $\mathrm{Cd}$ & $\mathrm{Zn}$ & $\mathrm{Pb}$ & $\mathrm{Cr}$ & $\mathrm{Mn}$ \\
\hline Intact soil & 44 & 24 & 2.8 & 60 & 56 & 58 & 716 \\
\hline Soil at $0 \mathrm{~cm}$ (surface) & 397 & 203 & 9.6 & 263 & 186 & 64 & 820 \\
\hline Soil at $20 \mathrm{~cm}$ & 76 & 75 & 7.3 & 114 & 67 & 81 & 754 \\
\hline Soil at $40 \mathrm{~cm}$ & 76 & 81 & 9 & 117 & 73 & 74 & 781 \\
\hline Soil at $60 \mathrm{~cm}$ & 70 & 75 & 7.9 & 111 & 73 & 73 & 775 \\
\hline Soil at $80 \mathrm{~cm}$ & 59 & 76 & 7 & 117 & 72 & 73 & 782 \\
\hline Soil at $100 \mathrm{~cm}$ & 59 & 56 & 7.8 & 109 & 75 & 76 & 819 \\
\hline Max. & 397 & 203 & 9.6 & 263 & 186 & 81 & 820 \\
\hline Min. & 59 & 56 & 7 & 109 & 67 & 64 & 754 \\
\hline SD & 134.532 & 53.924 & 1.003 & 61.076 & 46.617 & 5.540 & 26.051 \\
\hline
\end{tabular}

Table 4: Loosely bonded ions in soils

\begin{tabular}{|c|c|c|c|c|c|c|c|}
\hline \multicolumn{8}{|c|}{$(\mathrm{mg} / \mathrm{kg})$} \\
\hline Sample & $\mathrm{Ni}$ & $\mathrm{Cu}$ & Cd & $\mathrm{Zn}$ & $\mathrm{Pb}$ & $\mathrm{Cr}$ & $\mathrm{Mn}$ \\
\hline Intact soil & 5.2 & 4.675 & 2.3 & 8.425 & 35.28 & 7.75 & 45.25 \\
\hline Soil at $0 \mathrm{~cm}$ (surface) & 218.925 & 91.725 & 5.82 & 111.575 & 117.366 & 8.5 & 59 \\
\hline Soil at $20 \mathrm{~cm}$ & 10.325 & 6.725 & 5.75 & 8.275 & 42.3 & 9.25 & 44 \\
\hline Soil at $40 \mathrm{~cm}$ & 10.375 & 11.15 & 6.3 & 10.7 & 43.125 & 9.5 & 57.25 \\
\hline Soil at $60 \mathrm{~cm}$ & 10.325 & 5.075 & 5.53 & 7.6 & 42.375 & 10 & 351.25 \\
\hline Soil at $80 \mathrm{~cm}$ & 6.575 & 11.6 & 4.9 & 11.5 & 44.225 & 7.75 & 41.5 \\
\hline Soil at $100 \mathrm{~cm}$ & 8.325 & 10.5 & 4.575 & 5.15 & 46.05 & 8 & 47.5 \\
\hline Max. & 218.925 & 91.725 & 6.3 & 111.575 & 117.366 & 10 & 351.25 \\
\hline Min. & 6.575 & 5.075 & 4.575 & 5.15 & 42.3 & 7.75 & 41.5 \\
\hline SD & 85.639 & 33.869 & 0.635 & 42.082 & 30.141 & 0.889 & 123.247 \\
\hline
\end{tabular}


M. Esmaeili Bidhendi et al.

Table 5: Sulfides ions in soils

\begin{tabular}{|c|c|c|c|c|c|c|c|}
\hline \multicolumn{8}{|c|}{ (mg/kg) } \\
\hline Sample & $\mathrm{Ni}$ & $\mathrm{Cu}$ & $\mathrm{Cd}$ & $\mathrm{Zn}$ & $\mathrm{Pb}$ & $\mathrm{Cr}$ & $\mathrm{Mn}$ \\
\hline Intact soil & 0 & 0 & 0.086 & 0 & 6.49 & 0 & 0 \\
\hline Soil at $20 \mathrm{~cm}$ & 0 & 0 & 0 & 1.6 & 7.775 & 0.25 & 0 \\
\hline Soil at $40 \mathrm{~cm}$ & 0 & 4.8 & 1.476 & 3.6 & 13.35 & 1.75 & 0 \\
\hline Soil at $100 \mathrm{~cm}$ & 0 & 0 & 0.825 & 0 & 16.275 & 0.5 & 0 \\
\hline Max. & 67.1 & 22.35 & 1.62 & 22.1 & 21.576 & 9.6 & 253.25 \\
\hline Min. & 0 & 0 & 0 & 0 & 7.775 & 0.25 & 0 \\
\hline SD & 27.393 & 8.798 & 0.587 & 8.429 & 4.530 & 3.613 & 103.388 \\
\hline
\end{tabular}

Table 6: Organo-metallic ions in soils

\begin{tabular}{|c|c|c|c|c|c|c|c|}
\hline \multicolumn{8}{|c|}{ Chemical segregation analysis results - organic- metallic bond (mg/kg) } \\
\hline Sample & $\mathrm{Ni}$ & $\mathrm{Cu}$ & $\mathrm{Cd}$ & $\mathrm{Zn}$ & $\mathrm{Pb}$ & $\mathrm{Cr}$ & Mn \\
\hline Intact soil & 7.625 & 9.95 & 0.078 & 3.15 & 9 & 8 & 9.75 \\
\hline Soil at $20 \mathrm{~cm}$ & 3.95 & 11.325 & 0.5 & 4.125 & 10.775 & 11 & 9.75 \\
\hline Soil at $40 \mathrm{~cm}$ & 4.7 & 10.775 & 1.053 & 3.675 & 13.975 & 7.75 & 9.75 \\
\hline Soil at $100 \mathrm{~cm}$ & 3.25 & 9.9 & 1.6 & 2.725 & 11.58 & 8.25 & 10 \\
\hline Max. & 6.25 & 11.825 & 1.73 & 4.125 & 29.908 & 11 & 24 \\
\hline Min. & 3.25 & 9.9 & 0.5 & 2.725 & 10.775 & 7.75 & 9.75 \\
\hline SD & 1.035 & 0.705 & 0.472 & 0.573 & 7.349 & 1.324 & 5.778 \\
\hline
\end{tabular}

Normally, major portion of absorbed elements is found in loose bond that can be released into the environment as result of changes in physical and chemical changes in soil properties. Also, it should be stated that manganese sulfides in soil column are not formed. Therefore, it might be concluded that the environment is in oxidation condition.

\section{CONCLUSION}

According to the sample analysis of present study, the industrial leachates was found to have high levels of heavy metal and could be considered as hazardous and toxic to the environment. The results of present study clearly show that soil (i.e. natural bed soil) of studied area has a good potential to absorb heavy metals. This was evident from the obtained results in this study which indicated a reduction of all the metals by adsorption within the first 5 days. However, such adsorption is associated as loosely bonded ions that can easily be released into the environment by minor changes in physical and chemical conditions of soil. Hence, along with site selection of hazardous wastes' landfill, the cation exchange capacity of soil at various depths must be carefully determined. It is also concluded that removal of metals by soil profile does not mean an ultimate fate for contamination. In other words, the chemical bonds of metals with various soil phases are vital.

\section{ACKNOWLEDGMENTS}

The authors acknowledge financial and scientific support provided by the Faculty of Environment at the University of Tehran. 


\section{REFERENCES}

Al-Khashman, O. A., (2004). Heavy metal distribution in dust, street dust and soil from the work place in Karak Industrial Estate, Jordan Atmos. Environ., 38 (39), 6803-6812 (10 pages).

Allen, A. R., (2001). Containment landfills: The myth of sustainability. J. Eng. Geol., 60 (1-4), 3-19 (17 pages).

Aucott, M., (2006). The fate of heavy metals in landfills: A Review. Prepared for the industrial ecology, pollution prevention and the NY-NJ harbor. Project of the New York Academy of Sciences.

Bagchi, A., (1989). Design, construction and monitoring of sanitary landfills. John Wiley and Sons, New York.

Banat, K. M.; Howari, F. M.; Al-Hamad, A. A., (2005). Heavy metals in urban soils of central jordan: Should we worry about their environmental risks? Environ. Res., 97 (3), 258273 (16 pages).

Barrett, A.; Lawlor, J., (1995). The economics of waste management in ireland. Economic and Social Research Institute, Dublin.

Bulut, Y.; Baysal, Z., (2006). Removal of Pb (II) from wastewater using wheat bran. J. Environ. Manage., 78 (2), 107- 113 (7 pages).

Charlesworth, S.; Everett, M.; McCarthy, R.; Ordonez, A.; De Miguel, E., (2003). A comparative study of heavy metals concentration and distribution in deposited street dusts in a large and a small urban area: Birmingham and coventry, west midlands, UK. Environ. Int., 29 (5), 563573 (11 pages).

Chen, T. B.; Zheng, Y. M.; Lei, M.; Huang, Z. C.; Wu, H. T.; Chen, H.; Fan, K. K.; Yu, K.; Wu, X.; Tian, Q. Z., (2005). Assessment of heavy metal pollution in surface soils of urban parks in Beijing, China. Chemosphere, 60 (4), 542551 (10 pages).

Cheng, Z.; Zheng, Y.; Mortlock, R.; Van Geen, A., (2004). Rapid multi-element analysis of groundwater by highresolution inductively coupled plasma mass spectrometry. Anal. Bioanal. Chem., 379 (3), $512-518$ (7 pages).

Christensen, T. H.; Kjeldsen, P.; Bjerg, P. L.; Jensen, D. L.; Christensen, J. B.; Baun, A.; Albrechtsen, H. J.; Heron, G., (2001). Biogeochemistry of landfill leachate plumes. Appl. Geochem., 16 (7-8), 659-718 (59 pages).

EPA, (1992a). Integrated risk information system (IRIS). National centre for environmental assessment, Office of research and development, United State Environmental Protection Agency, Washington D.C.

EPA, (1992b). Flame atomic absorption spectrophotometry. Environmental Protection Agency. Revision 2.

EPA, (2007). Acid digestion of aqueous samples and extracts for total metals for analysis by FLAA or ICP Spectroscopy. Environmental Protection Agency. Method \# 3010A, Revision 1.

Fang, H. Y., (1995). Bacteria and tree root attack on liners, in: Sarby, R. W., (Ed.), Composition of leachate from waste disposal sites. Waste disposal by landfill: Green '93 Proceedings of a symposium on Geotechnics Related to the European Environment, Bolton, UK, Balkema, Rotterdam, 215-221 (7 pages).

Fatta, D.; Papadopoulos, A.; Loizidou, M., (1999). A Study on the landfill leachate and it's impact on the ground water quality of the greater area. Environ. Geochem. Hlth., 21 (2), 175-190 (16 pages).

Freeze, R. A.; Cherry, J. A., (1979). Ground Water. Prentice - Hall Inc., 604.

Futta, D.; Yoscos, C.; Haralambous, K. J.; Loizidou, M., (1997). An assessment of the effect of landfill leachate on groundwater quality. $6^{\text {th. }}$ Int. landfill symposium. S. Margherita di Pule, Gagliari, Italy. 181-187 (7 pages).

Gharaibeh, S. H.; Masad, A., (1989). Die problomatite der ahallbeseitingung in jordan. Fallstudie fur enstasicklungs lander. Wasser und Boden, 10, 620-622 (3 pages).

Karbassi, A. R.; Monavari, S. M.; Bidhendi, G. R. N.; Nouri, J.; Nematpour, K., (2008). Metal pollution assessment of sediment and water in the Shur River. Environ. Monitor. Assess., 147 (1-3), 107-116 (10 pages).

Langston, W., (1990). Toxic effects of metals and the incidence of metal pollution in marine coastal ecosystem, in: Furness, R. W.; Rainbow P. S., (Eds.), Heavy metals in the marine environment, Boca Raton. CRC Press Inc. 101-122 (22 pages).

Lee, G. F.; Jones L. A., (1993). Groundwater pollution by municipal landfills: Leachate composition, detection and water quality significance, Proc. Sardinia '93 IV International Landfill Symposium, Sardinia, Italy, 10931103 (11 pages).

Lee, G. F.; Jones, R. A.; Ray, C., (1986). Sanitary landfill leachate recycle. Biocycle., 27 (1), 36-38 (3 pages).

Lewis, R. J., (1991). Hazardous chemicals desk reference,

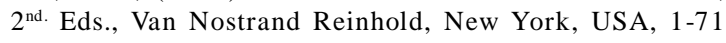
(71 pages).

Longe, E. O.; Enekwechi, L. O., (2007). Investigation on potential groundwater impacts and influence of local hydrology on natural attenuation of leachate at a municipal landfill. Int. J. Environ. Sci. Tech., 4 (1), 133140 (8 pages).

Low, K. S.; Lee, G. K.; Liew, S. C., (2000). Sorption of cadmium and lead from aqueous solutions by spent grain. Proc. Biochem., 36 (1), 59-64 (6 pages).

Mahvi, A. H., (2008). Application of agricultural fibers in pollution removal from aqueous solution. Int. J. Environ. Sci. Tech., 5 (2), 275-285 (11 pages).

Malakootian, M.; Nouri, J.; Hossaini, H., (2009). Removal of heavy metals from paint industries wastewater using Leca as an available adsorbent. Int. J. Environ. Sci. Tech., 6 (2), 183-190 (8 pages).

Nameni, M.; Alavi Moghadam, M. R.; Arami, M., (2008). Adsorption of hexavalent chromium from aqueoussolutions by wheat bran. Int. J. Environ. Sci. Tech., 5 (2), 161-168 (8 pages).

Nouri, J.; Mahvi, A. H.; Jahed, G. R.; Babaei, A. A., (2008). Regional distribution pattern of groundwater heavy metals resulting from agricultural activities. Environ. Geol. 55 (6), 1337-1343 (7 pages).

Okafor, E. Ch.; Opuene, K., (2007). Preliminary assessment of trace metals and polycyclic aromatic hydrocarbons in the sediments. Int. J. Environ. Sci. Tech., 4 (2), 233-240 (8 pages).

Panjeshahi, M. H.; Ataei, A., (2008). Application of an environmentally optimum cooling water system design in water and energy conservation. Int. J. Environ. Sci. Tech., 5 (2), 251-262 (12 pages). 
Pekey, H., (2006). The distribution and sources of heavy metals in Izmit Bay surface sediments affected by a polluted stream. Mar. Pollut. Bull., 52 (10), 1197-1208 (12 pages).

Qasim, S. R.; Chiang, W., (1994). Sanitary landfill leachate. CRC Press.

Suthar, S.; Singh, S., (2008). Vermicomposting of domestic waste by using two epigeic earthworms (Perionyx excavatus and perionyx sansibaricus). Int. J. Environ. Sci. Tech., 5 (1), 99106 (8 pages).
Vasanthi, P.; Kaliappan, S.; Srinivasaraghavan, R., (2008). Impact of poor solid waste management on ground water. Environ. Monit. Assess., 143 (1-3), 227-238 (11 pages). Zheng, C.; Bennett, G. D.; Andrews, C. B., (1991). Analysis of groundwater remedial alternatives of a superfund site. Groundwater, 29 (6), 838-848 (11 pages).

\author{
AUTHOR (S) BIOSKETCHES \\ Esmaeili Bidhendi, M., M.Sc., Graduate Faculty of the Environment, University of Tehran, P. O. Box 14155-6135, Tehran, Iran. \\ Email:m.esmaieli@gmail.com \\ Karbassi, A. R., Ph.D., Assistant Professor, Graduate Faculty of the Environment, University of Tehran, P. O. Box 14155-6135, Tehran, \\ Iran. Email: arkarbassi738@yahoo.com \\ Baghvand, A., Ph.D, Assistant Professor, Graduate Faculty of the Environment, University of Tehran, P. O. Box 14155-6135, Tehran, Iran. \\ Email: baghvand@ut.ac.ir \\ Saeedi, M., Ph.D, Assistant Professor, Environmental Research Laboratory, School of Civil Engineering, Iran University of Science and \\ Technology, Tehran, Iran. \\ Email: msaeedi@iust.ac.ir \\ Pejman, A. H., M.Sc., Graduate Faculty of the Environment, University of Tehran, P. O. Box 14155-6135, Tehran, Iran. \\ Email:ahp9325@gmail.com
}

